Reprod. Nutr. Dévelop., 1986, 26 (5 A), 1105-1114.

\title{
A radioimmunoassay of chicken growth hormone using growth hormone produced by recombinant DNA technology : validation and observations of plasma hormone variations in genetically fat and lean chickens
}

\author{
G. PICAPER, B. LECLERCQ* $\left.{ }^{1}\right)$, A. SAADOUN*, P. MONGIN*
}

Centre hospitalier régional d'Orléans

B.P. 29, 45046 Orléans, France

(*) Station de Recherches avicoles, I.N.R.A.

Nouzilly 37380 Monnaie, France.

Summary. A radioimmunoassay (RIA) of chicken growth hormone (c-GH) has been developed using growth hormone produced by recombinant DNA technology. The best rabbit antiserum was used at 1/300,000 final dilution. Hormone labelling by iodine-125, achieved by chloramine $\mathrm{T}$, allowed a specific activity of $3.7 \mathrm{MBq} / \mu \mathrm{g}$. The equilibrium curves show that optimal conditions of incubation were reached at room temperature for 24 $h$. This RIA used a second sheep antibody which precipitated the whole $\mathrm{c}-\mathrm{GH}$ bound to the first antibody in the presence of polyethylene glycol solution $(6 \%)$ at room temperature for $30 \mathrm{~min}$. In our conditions, sensitivity was about $30 \mathrm{pg}$ of $\mathrm{c}-\mathrm{GH}$ per tube. Coefficient of variation was around $10 \%$. No cross reaction was found with avian LH and prolactin. Thyrotrophinreleasing hormone (TRH) injection to young chickens induced 20 -fold higher plasma c-GH concentrations. Simultaneous injection of somatostatin and TRH slightly reduced these concentrations. Hypoglycemia induced by insulin led to a drop of the plasma $\mathrm{c}-\mathrm{GH}$ concentration. Conversely, refeeding or glucose load induced slight increases of the c-GH level. Genetically fat chickens tended to exhibit higher plasma c-GH concentrations than lean chickens.

\section{Introduction.}

Most radioimmunoassays (RIA) of avian growth hormone have been based on hormone extracted from the hypophysis (Harvey and Scanes, 1977; Proudman and Wentworth, 1978 ; Leung et al., 1984). Since chicken growth hormone $(\mathrm{c}-\mathrm{GH}$ ) has been obtained by recombinant DNA technology (Souza et al., 1984), we have developed a RIA using this source of $\mathrm{c}-\mathrm{GH}$ which protects against hypophyseal contaminants. A similar assay has been carried out recently

(1) Reprints are to be requested from $B$. Leclercq 
by Proudman (1984). The present paper describes and validates our RIA. Moreover, c-GH concentrations have been compared in the plasma of genetically fat and lean chickens according to feeding conditions.

\section{Material and methods.}

c-GH. - Chicken growth hormone was obtained from AMGEN Biologicals (1900 Oak Terrace Lane, Thousand Oaks, USA). Its purity was about $95 \%$ according to silver stain SDS electrophoresis. It was presented as freeze-dried material from a buffer solution containing $0.2 \%$ lactose, $0.2 \%$ mannitol and $0.25 \%$ sodium bicarbonate ( $\mathrm{pH} 8.5$ ). $1.5 \mathrm{mg}$ were dissolved in $13.5 \mathrm{ml}$ of phosphate buffer $0.01 \mathrm{M}$ (pH7.5) saline $(0.15 \mathrm{M} \mathrm{NaCl}$ ) sterile solution (PBS). This solution was divided into 30 fractions of about $50 \mu \mathrm{g}$ for immunizing rabbits. The remaining $\mathrm{c}-\mathrm{GH}$ was divided into 100 fractions of $5 \mu \mathrm{g}$ for labelling or standard curves and kept at $-30^{\circ} \mathrm{C}$.

Hormone labelling. - The growth hormone was labelled according to the chloramine $T$ method (Hunter and Greenwood, 1962). Five microliters of sterile solution containing $5 \mu \mathrm{g}$ of hormone and $10 \mu \mathrm{l}$ of phosphate buffer $10.5 \mathrm{M}$, $\mathrm{pH}$ 7.5) solution were added to $37 \mathrm{MBq} \mathrm{Na}{ }^{125}$ l carrier-free diluant (IMS 30 ; Amersham, France). Five microliters of chloramine $T(4 \mathrm{mg} / \mathrm{ml})$ solution were added in a closed fume cupboard and allowed to react for $30 \mathrm{sec}$. The reaction was stopped by adding $10 \mu \mathrm{l}$ of a sodium metabisulphite $(5 \mathrm{mg} / \mathrm{ml})$ solution. Fifty $\mu l$ of potassium iodide $(10 \mathrm{mg} / \mathrm{ml})$ solution was then added. Free iodine was separated from the iodine-labelled proteins by chromatography on G25 Sephadex equilibrated with a solution containing phosphate $(0.04 \mathrm{M}, \mathrm{pH} 7.5)$ buffer, sodium chloride (0.15 M), EDTA $(0.01 \mathrm{M})$, bovine serum albumin $(0.5 \%)$ and $\mathrm{NaN}_{3}(0.1 \%)$ (PBS-BSA). The labelled hormone peak was then diluted to a working dilution of $20,000 \mathrm{cpm} / 100 \mu \mathrm{l}$.

Antibodies. - Two rabbits were immunized with an emulsion obtained by mixing (Vortex) for $10 \mathrm{~min}$ a fraction $(50 \mu \mathrm{g})$ of the hormone and $500 \mu \mathrm{l}$ of complete Freund's adjuvant. This emulsion was injected subcutaneously in 40 places on the back of rabbits once weekly for 4 weeks. On the 5 th week, they were intravenously injected with a $500-\mu$ l fraction of the hormone. Blood was collected by cardiac puncture 5 and 7 days later. The same procedure was followed again 15 days later using incomplete Freund's adjuvant. Over the three successive immunizations it was possible to collect 6 serum samples ( 3 per animal). Each serum was tested for its ability to bind $\mathrm{I}^{125}$-labelled $\mathrm{c}-\mathrm{GH}$. The second antibody (anti-rabbit sheep serum) was obtained from the Station de Physiologie de la Reproduction (Nouzilly) and used at a final dilution of 1 : 125 .

Radioimmunoassay (RIA). - - Double antibody c-GH RIA was conducted in $12 \times 75 \mathrm{~mm}$ disposable polypropylene tubes with a conical bottom. The standard hormone preparation and unknown samples were added in a 100- $\mu$ l volume. 
Chicken $\mathrm{GH}$ was serially diluted and assayed in concentrations ranging from 32 to $0.5 \mathrm{ng} / \mathrm{ml}$. All standards and unknown samples were diluted in PBS-BSA buffer. One hundred microliters of $\mathrm{c}-\mathrm{GH}$ antiserum (lot $\mathrm{GH} 2 \mathrm{~d}$ ), diluted to $10^{-5}$ in PBSBSA solution containing normal rabbit serum $\left(10^{-2}\right.$ concentration), were added to each tube. One hundred microliters of 125 -labelled $\mathrm{c}-\mathrm{GH}$ containing approximately $2.10^{5} \mathrm{dpm}$ in PBS-BSA solution were added to each tube. The tubes were incubated at room temperature for $24 \mathrm{~h}$. Optimal conditions of incubation were determined by incubating labelled c-GH with $\mathrm{GH} 2 \mathrm{~d}$ antibodies in the following conditions : $+4^{\circ} \mathrm{C}$, room temperature $\left(21^{\circ} \mathrm{C} \pm 3{ }^{\circ} \mathrm{C}\right)$ or $37^{\circ} \mathrm{C}$. The radioactivity of the complex was measured after $1,2,4,18,24$, and $48 \mathrm{~h}$ of incubation. Thereafter, $50 \mu \mathrm{l}$ of a $1: 5$ dilution of ovine anti-rabbit gamma globulin in PBS-BSA buffer were added and immediately afterwards, $1 \mathrm{ml}$ of polyethylene glycol at a $6 \%$ concentration in PBS-BSA buffer was added to each tube. The assay was allowed to incubate at room temperature for $30 \mathrm{~min}$. After final incubation, $1 \mathrm{ml}$ of PBS-BSA solution was added to each tube and all the tubes were centrifuged at $3,000 \times \mathrm{g}$ for $10 \mathrm{~min}$. The supernatant was decanted and the precipitate counted in an automatic gamma counter (CG 4000 Kontron France or Packard A5412).

Quality control. - The sensitivity was the lower limit of detection calculated by precision measurement of the zero dose. Such defined sensitivity consequently represented a special case in the general concept of the precision profile. The precision profile included a plot of the precision (relative error $=\triangle \mathrm{C} / \mathrm{C}$ ) of $\mathrm{c}-\mathrm{GH}$ measurement against the corresponding $\mathrm{c}-\mathrm{GH}$ concentration $(\mathrm{C})$. This relationship was characterized by calculating the standard deviation $(\triangle \mathrm{C})$ of ten replicates at each of 8 standard points along the dose-response curve.

The recovery test was performed by measuring the concentration of standard hormone (S) added to different cockerel sera (C). Measured concentrations were compared to calculated values. The ratio of measured concentration to calculated concentration was the recovery ratio.

The dilution test was performed by measuring the hormone concentration of serial dilutions of a high concentration of plasma c-GH diluted in PBS-BSA buffer.

The dose-response curves for chicken prolactin (cPRL) (gift of Dr. Chadwick) and the chicken LH fraction AE1 (gift of Dr. F. J. Cunningham) were determined in the RIA to evaluate specificity.

c-GH concentrations were measured in young meat-type chickens 13 or 6 weeks of age), laying hens (ISA Brown) and adult cockerels (ISA Brown). Sera from hypophysectomized chickens (Goussopoulos, 1978) were also analysed.

The effects of TRH (L-pyroglutamyl-L-histidyl-L-prolinamide) and somatostatin (SIGMA) were also measured. Fifteen 5-week old chickens were starved for $16 \mathrm{H}$. They were intravenously injected with either saline solution, $5 \mu \mathrm{g}$ of TRH, or $5 \mu \mathrm{g}$ of TRH plus $2.5 \mu \mathrm{g}$ of somatostatin. Blood samples were collected on heparin by cardiac puncture $5 \mathrm{~min}$ after injection. The effects of exogenous insulin on plasma c-GH concentrations were also investigated during two experiments. In the first experiment, five 5-week old male broilers (Hubbard) were 
injected with porcine insulin (1 IU/ kg live weight) in the thigh muscles after $16 \mathrm{~h}$ of fasting. Five control birds were injected with saline. Blood samples were collected $90 \mathrm{~min}$ after injection, as described previously. In the second experiment, 6 groups of eight 5-week old male broilers (Arbor Acres) were injected with porcine insulin (1 $\mathrm{IU} / \mathrm{kg}$ live weight) ; 6 control groups were injected with saline. Blood samples were collected 0, 15, 30, 60, 90 and 120 min after injection.

Plasma cGH concentrations were also compared in fat and lean male broilers. The birds came from the F9 generation of Nouzilly experimental lines (Leclercq et al., 1980) and were 5 weeks old. In the first experiment, 4 groups of 8 birds per line were fasted $16 \mathrm{~h}$ and then refed a complete diet $(13 \mathrm{MJ} / \mathrm{kg}, 200 \mathrm{~g}$ crude protein $/ \mathrm{kg}$ ). Blood samples were taken by cardiac puncture $0,10,15,20,30,45$, 60 and 90 after refeeding. The birds were sampled twice : one group at 0 and 30 $\mathrm{min}$, one at 10 and $45 \mathrm{~min}$, one at 15 and $60 \mathrm{~min}$ and one at 20 and $90 \mathrm{~min}$ after refeeding. In the second experiment, a glucose tolerance test $(2 \mathrm{~g} / \mathrm{kg}$ live weight) was performed on 56 male chickens per line. Blood samples were collected 0 , $10,15,30,45,60$ and $90 \mathrm{~min}$ after the glucose load.

\section{Results.}

The results of eluting the products of iodination on Sephadex G25 are shown in figure 1. It may be concluded that the mean yield of labelling was about $48 \%$. The number of iodine atoms to a $\mathrm{c}-\mathrm{GH}$ molecule was $1: 3$. When the protein peak eluted in the G25 Sephadex chromatography was chromatographed again, only one peak of radioactivity was obtained. So, G25 Sephadex chromatography was sufficient.

As shown in figure 2, after the last immunization, the curves of antiserum binding capacity according to dilution revealed that the best antibody was $\mathrm{GH} 2 \mathrm{~d}$ which exhibited a binding capacity of $30 \%$ at $3.10^{-5}$ dilution. In the case of an

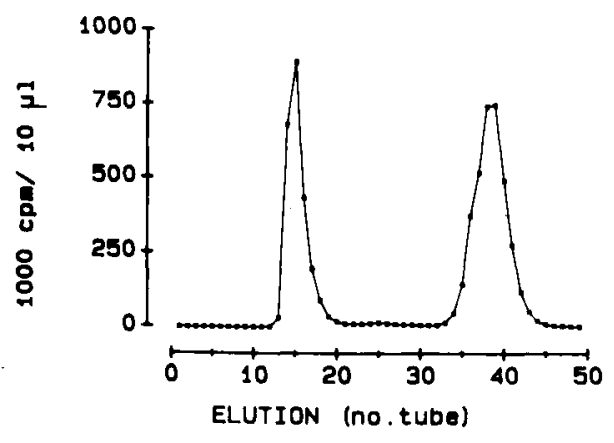

FIG. 1. - Elution curve of 125 lodine activity by chromatography on Sephadex G 25.

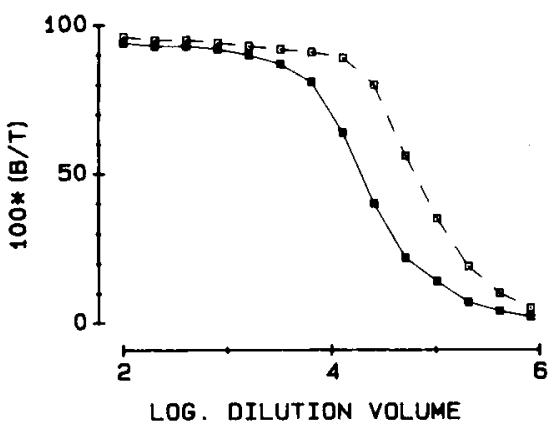

FIG. 2. - Binding capacity of antibody GH1D (a) and $G H 2 d$ ( $\square$ ) according to dilution volume of antibody. 
excess of antibodies, binding capacity was over $90 \%$, showing the excellent immunoreactivity of the labelled hormone. As shown in figure 3, optimal conditions of incubation were $24 \mathrm{~h}$ at room temperature. The values of the coefficient of variation of $\mathrm{c}-\mathrm{GH}$ determination, according to hormone concentration, are given in table 1 . These values were inferior to $10 \%$ between concentrations of 1 and $32 \mathrm{ng} / \mathrm{ml}$. At that time, a $30 \mathrm{pg}$ sensitivity was found. A recovery test was performed on 3 sera of male broilers. The results are presented in table 2. Recovery percentage was estimated as $97 \pm 6 \%$ between 4 and $16 \mathrm{ng} / \mathrm{ml}$. Lastly, the dilution test with buffer showed a linear regression line

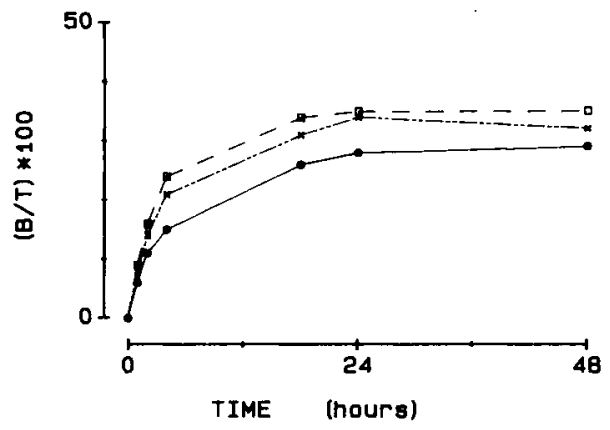

FIG. 3. - Equilibrium curves. Effects of time and temperature of incubation on binding of $\mathrm{c}-\mathrm{GH}$ and $\mathrm{GH} 2 d$ antiserum (०), $+4{ }^{\circ} \mathrm{C} ;(\square)+21^{\circ} \mathrm{C} ;(\mathrm{X})+37^{\circ} \mathrm{C}$.

FIG. 4. - Effect of exogenous insulin (1 IU/kg live weight) on plasma glucose and c- $\mathrm{GH}$ of 5-week old chickens. ( $(\mathbf{-}-\mathrm{a})$, insulin ; ( $\square--\square)$, saline.
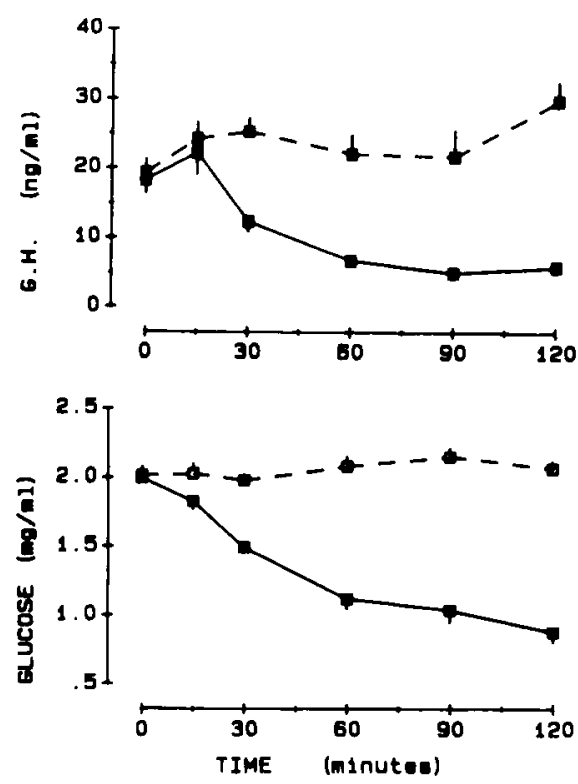

TABLE 1

Coefficient of variation $(\%)$ of $c-G H$ determination according to hormone concentration $(\mathrm{ng} / \mathrm{ml})$

Coefficient of variation

$\frac{\Delta C}{C} \times 100$
c-GH concentration

(C)

\begin{tabular}{rr}
20 & 0.5 \\
10 & 1 \\
5 & 2 \\
4 & 4 \\
4 & 8 \\
6 & 16 \\
10 & 32 \\
15 & 64 \\
\hline
\end{tabular}


between $\mathrm{c}-\mathrm{GH}$ determination $(y)$ and the decimal logarithm of dilution $(x)$ : $y=14.8 \times-0.612$; the coefficient of correlation was 0.999 . No cross reaction was observed with c-LH or C-PRL, as shown in table 3.

TABLE 2

Recovery test of c-GH performed on three male-broiler sera (*)

\begin{tabular}{ccccc}
\hline Serum $\mathrm{n}^{\circ}$ & $\begin{array}{c}\mathrm{c}-\mathrm{GH} \\
\text { concentration } \\
\text { (ng/ml) }\end{array}$ & $\begin{array}{c}\text { Expected } \\
\text { c-GH } \\
\text { concentration } \\
(\mathrm{ng} / \mathrm{ml})\end{array}$ & $\begin{array}{c}\text { Measured } \\
\text { c-GH } \\
\text { concentration } \\
(\mathrm{ng} / \mathrm{ml})\end{array}$ & $\begin{array}{c}\text { Recovery } \\
\text { ratio }\end{array}$ \\
\hline 1 & 1.8 & 8.9 & 9.4 & 1.06 \\
& & 4.9 & 5.1 & 1.05 \\
2 & 2.9 & 2.6 & 0.89 \\
\hline 3 & 2.2 & 9.1 & 8.3 & 0.91 \\
& & 5.1 & 4.8 & 0.94 \\
& 2.4 & 3.1 & 3.0 & 0.96 \\
\hline \multirow{2}{*}{3} & 9.2 & 9.2 & 1.00 \\
mean & & 3.2 & 4.9 & 0.95 \\
standard deviation & & & 3.1 & 0.99 \\
\hline
\end{tabular}

(*) 4,8 or $16 \mathrm{ng} \mathrm{c}-\mathrm{GH} / \mathrm{ml}$ were successively added to an equal volume of serum.

TABLE 3

Test of cross-reactivity of $c-P R L$ and $c-L H$ with $c-G H$

\begin{tabular}{rrr}
\hline $\begin{array}{c}\text { c-PRL added } \\
\text { (ng/ml) }\end{array}$ & $\begin{array}{c}\text { c-LH added } \\
\text { (ng/ml) }\end{array}$ & B/Bo \\
\hline 78 & & 1.01 \\
156 & & 1.01 \\
312 & & 0.97 \\
625 & & 1.02 \\
1,250 & & 1.02 \\
2,500 & & 0.96 \\
5,000 & & 0.95 \\
10,000 & 62 & 1.10 \\
\hline & 125 & 0.91 \\
& 250 & 0.95 \\
& 500 & 0.96 \\
& 1,250 & 0.93 \\
\hline
\end{tabular}

The effects of age, hypophysectomy, exogenous insulin, THR and TRH + somatostatin are presented in table 4 . High values were observed in growing chickens. During the adult period no $\mathrm{c}-\mathrm{GH}$ could be detected in male plasma and only a small amount in that of the females. Plasma from hypophysectomized chickens contained very low c-GH concentrations, but they 
were significantly different from zero. The injection of TRH led to 20-fold increases of $\mathrm{c}-\mathrm{GH}$ when the blood was collected $5 \mathrm{~min}$ later. The addition of somatostatin to TRH had only a weak effect on the c-GH level. Lastly, exogenous insulin injection to starved growing chickens induced a significant drop in both plasma glucose and c-GH $90 \mathrm{~min}$ later. This effect of insulin was investigated again in a second experiment ; the results are given in figure 4. Exogenous insulin led to a parallel decrease in both plasma glucose and $\mathrm{c}-\mathrm{GH}$; minimal levels were reached 90 min after injection.

\section{TABLE 4}

Effect of age, exogenous insulin, TRH $(5 \mu \mathrm{g}), T H R(5 \mu \mathrm{g})+$ somatostatin $(2.5 \mu \mathrm{g})$ and hypophysectomy on plasma $c-G H$ concentration (mean \pm standard deviation)

\begin{tabular}{lccc}
\hline & $\begin{array}{c}\mathrm{c}-\mathrm{GH} \\
(\mathrm{ng} / \mathrm{ml})\end{array}$ & No birds & $\begin{array}{c}\text { Plasma glucose } \\
(\mathrm{mg} / \mathrm{ml})\end{array}$ \\
\hline 3-week-old chicks & $14 \pm 0.6$ & 3 & \\
6-week-old chicks & $30 \pm 0.7$ & 3 & \\
Laying hens & $6 \pm 0.1$ & 6 & \\
Adult cockerels & undetectable & 3 & $1.43 \pm 0.10$ \\
\hline Hypophysectomised chicks & $4.55 \pm 0.38$ & 6 & $2.30 \pm 0.06$ \\
\hline Insulin-injected chicks & $4.56 \pm 0.87\left(^{*}\right)$ & 5 & \\
Controls (saline) & $15.40 \pm 2.30^{*}$ & 4 & \\
\hline TRH injected chicks & $197.50 \pm 43.1\left(^{*}\right)$ & 4 & \\
TRH + somatostatin & $188.20 \pm 23.4\left(^{*}\right)$ & 4 & \\
Controls & $9.95 \pm 1.26$ & 4 & \\
\hline
\end{tabular}

(*) significantly different from controls $(P<0.01)$.

Genetically lean (LL) and fat (FL) chickens were compared in two experiments. The effects of a glucose load $(2 \mathrm{~g} / \mathrm{kg}$ live weight) are illustrated in figure 5. Glucose injection induced a weak increase of $\mathrm{c}-\mathrm{GH}$ in both lines. No

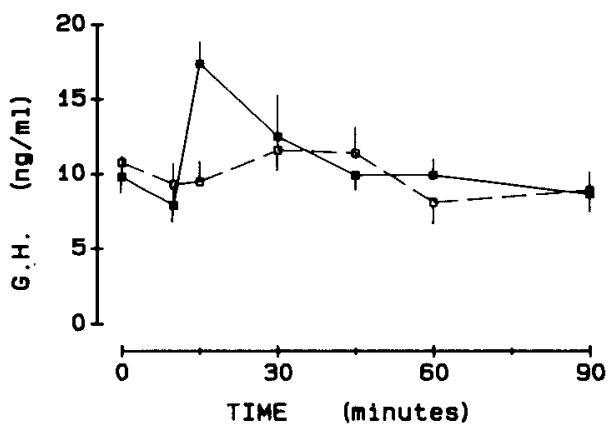

FIG. 5. - Effect of a glucose load $(2 \mathrm{~g} / \mathrm{kg}$ live weight) on plasma $\mathrm{c}-\mathrm{GH}$ concentration of lean ( $\square$ ) or fat ( $\square$ ) chickens.

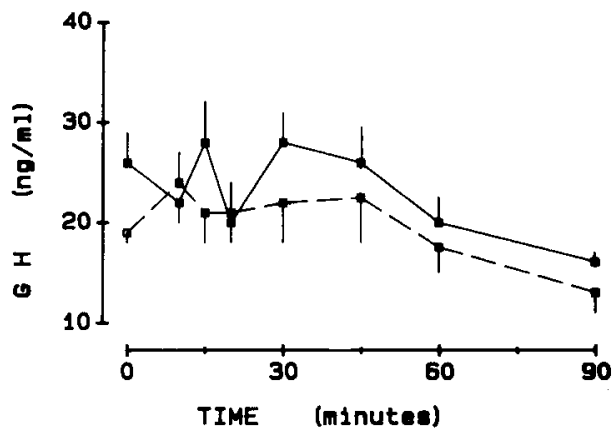

FIG. 6. - Effect of refeeding on plasma c-GH concentration of lean ( $\square$ ) or fat (D) chickens. 
difference was observed between lines. In the second experiment, starved chickens of both lines were refed with a complete diet. The results are shown in figure 6. Refeeding induced a slight increase of $\mathrm{c}-\mathrm{GH}$ in both lines. However, in this experiment, plasma $\mathrm{c}-\mathrm{GH}$ concentrations in $\mathrm{FL}$ chickens were significantly higher than in LL subjects. The results of the analysis of variance showed a significant effect of time $(F=2.73, P<0.01)$ and of genotype $(F=4.66$; $P<0.05)$ and no interaction effect $(F=0.63 ; N S)$.

\section{Discussion.}

The chicken GH RIA developed in our laboratory and presented here seemed to be very specific. No cross reactivity was observed with c-PRL. This RIA also gave classic responses to biological tests. The injection of TRH and TRH + somatostatin induced similar effects to those described by Harvey et al. (1978a) and Harvey and Scanes (1984). As reported by the first authors, somatostatin was not able to suppress the stimulatory effect of TRH. Moreover, the effects of plasma glucose in the present study agree very closely with those observed by Harvey et al. (1978b). The administration of exogenous insulin significantly depressed the level of $\mathrm{c}-\mathrm{GH}$ in the plasma of fasted birds, confirming that chicken reaction from this viewpoint is opposite to that of mammals (Roth et al., 1963). Our results (fig. 5) show that plasma $\mathrm{GH}$ decrease occurs simultaneously with plasma glucose decrease. Conversely, enhancement of plasma glucose after a glucose load or a meal can induce only a weak increase of plasma $\mathrm{GH}$. This agrees also very well with the observation of Harvey et al. (1978b). So, we may conclude that our antibodies were able to bind specifically with $\mathrm{c}-\mathrm{GH}$ and that the RIA described here was specific to that hormone.

Significantly higher growth hormone concentrations were found in the plasma of fat chickens than in that of lean chickens after refeeding. However, no difference was observed after a glucose load. In both cases, plasma c-GH concentration tended to increase about $30 \mathrm{~min}$ after feeding or glucose load. If significant, line effect could be explained by the slightly lower growth rate of the lean mass in fat birds since Scanes et al. (1984) showed that plasma c-GH was negatively correlated with growth rate. High levels of growth hormone were also found in hypothyroidic obese chickens (Scanes et al., 1984), but this type of obesity is very particular. The discrepancies between results obtained after refeeding or glucose load are perhaps due to a difference in the stimuli of glucose and insulin and therefore of $\mathrm{c}-\mathrm{GH}$ secretion. This last aspect has to be more thoroughly investigated. It has been observed that mammal obesities are frequently accompanied by abnormally depressed plasma $\mathrm{GH}$ concentrations (Sinha et al., 1975 ; Martin et al., 1978 ; Finkelstein et al., 1986). Our results and those of Scanes et al. (1984) suggest that excessive fattening in birds leads to a response opposite to that of mammalian models of obesity. 
Acknowledgements. - The authors thank Dr J. Charrier (ENSA, Montpellier) for providing the serum of hypophysectomized chickens and Dr Chadwick for the chicken prolactin. The excellent technical assistance of M. Derouet and G. Guy is gratefully acknowledged.

Résumé. Dosage radioimmunologique de l'hormone de croissance de poulet; applications à deux lignées différant génétiquement pour l'état d'adiposité.

Un dosage radio-immunologique de I'hormone de croissance de poulet (c-GH) a été mis au point à partir d'hormone produite par génie génétique. Le meilleur antisérum de lapin peut être utilisé à la dilution finale $1: 300-000$. L'hormone est marquée par la méthode utilisant la chloramine $T$. Les meilleures conditions pour obtenir le complexe antigèneanticorps sont $24 \mathrm{~h}$ a $21^{\circ} \mathrm{C}$. Ce dosage met en œuvre un second anticorps de mouton antilapin qui précipite le complexe antigène-anticorps en présence de polyéthylène glycol. Le coefficient de variation moyen est de $10 \%$. Aucune réaction croisée n'a été observée avec la prolactine ou LH de poulet. La thyrotrophin-releasing-hormone (TRH) injectée à de jeunes poulets multiplie par 25 la concentration plasmatique de c-GH. L'injection simultanée de somatostatine réduit faiblement l'effet de TRH. L'hypoglycémie induite par l'insuline exogène entraîne une baisse importante de $\mathrm{c}-\mathrm{GH}$ plasmatique. A l'inverse un repas ou une charge de glucose tendent à accroître la concentration du plasma en c-GH. A la suite d'une réalimentation, des poulets génétiquement gras présentent des teneurs plasmatiques de cGH plus élevées que celles de poulets maigres. Aucune différence n'est trouvée entre génotypes dans le cas d'un test de tolérance au glucose.

\section{Références}

FINKELSTEIN J. A., JERVOIS P., MENADUE M., WILLOUGHBY J. O., 1986. Growth hormone and prolactine secretion in genetically obese Zucker rats. Endocrinology, 118, 1233-1236.

GOUSSOPOULOS J., 1978. Etude de la croissance relative post-natale chez le poulet : principaux organes et tissus, muscles et os individuels. Influence de l'hypophysectomie. Th. Doct. Univ., Montpellier.

HARVEY S., SCANES C., 1977. Purification and radioimmunoassay of chicken growth hormone. J. Endocr., 73, 321-329.

HARVEY S., SCANES C. G., 1984. Comparative stimulation of growth hormone secretion in anaesthetized chickens by human pancreatic growth hormone releasing factor (hp GRF) and thyrotrophin releasing hormone (TRH). Neuroendocrinology, 39, 314-320.

HARVEY S., SCANES C. G., CHADWICK A., BOLTON N. J., 1978a. The effect of thyrotropin releasing hormone (TRH) and somatostatin (GHRIH) on growth hormone and prolactin secretion in vitro and in vivo in the domestic fowl. Neuroendocrinology, 26, 249-260.

HARVEY S., SCANES C. G., CHADWICK A., BOLTON N. J., 1978b. Influence of fasting, glucose and insulin on the levels of growth hormone and prolactin in the plasma of domestic fowl (Gallus domesticus). J. Endocr., 76, 501-506.

HUNTER W. M., GREENWOOD F. C., 1962. Preparation of iodine 131 labelled human growth hormone of high specific activity. Nature, 194, 495-496.

LECLERCO B., BLUM J. C., BOYER J. P., 1980. Selecting broilers for low or high abdominal fat : initial observations. Brit. Poult. Sci, 21, 107-113.

LEUNG F. C., TAYLOR J. E., STEELMAN S. L., BENNET C. D., RODKEY J. A., LONG R. A., SERIO R., WEPPELMAN R. M., OLSON G., 1984. Purification and properties of chicken growth hormone and the development of a homologous radioimmunoassay. Gen. Comp. Endocrinol., 56, 389-400.

MARTIN R. J., WANGSNESS P. J., GAHAGAN J. H., 1978. Diurnal changes in serum metabolites and hormones in lean and obese Zucker rats. Horm. Metab. Res., 10, 187-192.

PROUDMAN J. D., 1984. Recombinant derived chicken growth hormone used for radioimmunoassay. Proc. Soc. exp. Biol. Med., 175, 417-419. 
PROUDMAN J. A., WENTWORTH B. C., 1978. Radioimmunoassay of turkey growth hormone. Gen. Comp. Endocrinol., 56, 389-400.

ROTH J., GLICK S. M., YALOW R. S., BERSON S. A., 1963. Hypoglycaemia : a potent stimulus to secretion of growth hormone. Science, 140, 987-988.

SCANES C. G., HARVEY S., MARSH J. A., KING D. B., 1984. Hormones and growth in poultry. Poult. Sci., 63, 2062-2074.

SINHA Y. N., SALOCKS C. B., VANDERLAAN W. P., 1975. Prolactin and growth hormone secretion in chemically-induced and genetically obese mice. Endocrinology, 97, 1386-1391.

SOUZA L. M., BOONE T. C., MURDOCK D., LANGLEY K., WYPYCH J., FENTON D., JOHNSON S., LAI P. H., EVERETT R., HSU R. Y., BOSSELMAN R., 1984. Application of recombinant DNA technologies to studies of chicken growth hormone. J. exp. Zool., 232, 465-473. 